\title{
A qualitative survey for the academic libraries in the throes of a great recession
}

\author{
Petros Kostagiolas ${ }^{1}$, Christina Banou ${ }^{2}$, Stella Vazaiou ${ }^{3}$, Nikolaos Kapellas ${ }^{4}$ \\ ${ }^{1}$ Assistant Prof. Dep. Archives, Library Science and Museology, Faculty of Information Science and Informatics, Ionian University. \\ Greece \\ ${ }^{2}$ Assistant Prof. Dep. Archives, Library Science and Museology, Faculty of Information Science and Informatics, Ionian University. \\ Greece \\ ${ }^{3}$ MSc. PhD candidate Dep. Archives, Library Science and Museology, Faculty of Information Science and Informatics, Ionian \\ University. Greece \\ ${ }^{4}$ MSc. Dep. Archives, Library Science and Museology, Faculty of Information Science and Informatics, Ionian University. Greece
}

\begin{abstract}
Over the last years the economic crisis affected the wide range of activities and services that Academic Libraries provide. On the other hand the demand for such services is increasing due to the reduced individual income of the librarie's users. The management of libraries is sometimes forced to make agonizing decisions regarding further shrinkage or/and mergers. An alternative to this scenario involves a strategy for advocating the value and developing alliances and collaborations among the Academic Libraries. The paper focuses on academic libraries in Greece during the economic crisis of the last five years with the aim to investigate problems and difficulties as well as challenges; changes brought about are discussed proposing at the same time a framework not only for overcoming the difficulties but also for exploiting the new opportunities. Initially, an overview of the role and function of academic libraries is presented with emphasis on their social character. Key leadership issues are explored in the context of on going restructuring attempts in order to establish viable operational models for academic institutions.
\end{abstract}

\section{Introduction}

The global economic crisis of 2008 has variously affected the Greek economy over the last few years. Economic phenomena have complicated socioeconomic roots that raise a wide array of issues and questions. These questions are related to values, comprehending existing problems, social conditions and cultural as well as political issues. As it has been shown from the global economic recessions of the past, hard times apart from problems create opportunities and form challenges while roles are constantly redefined [1].Undeniably, the hard economic pressures in Greece and elsewhere call for solutions through innovation and creativity. Academic libraries are expected not only to survive but mainly to take a leading role in higher education, scholarly dissemination and communication, information literacy and reading policy etc. [2].For this purpose, the exploitation of new information technologies as well as synergies has undeniably been among the opportunities presented up to this point. But pressing questions that call for answers set the scene in a world where economies sometimes in certain historical junctures collapse, as expectations and needs of the readers may grow slower than technologies.
The so-called "public debt crisis" mainly affected Greece, Ireland, Spain, Portugal and Italy. Regarding Greece, the economic crisis appeared in 2009, and has been actually related to innate structural deficiencies of the Greek public sector and its potential inability to control its ballooning debt [3].In a broader sense, however, this is a Euro zone economic crisis related to the European Monetary Union (EMU) structure as well as in the strategy for safeguarding a "good euro" as a world currency. Greece was forced to resort to the Financial Support Mechanism in March 2010, with the participation of other Eurozone countries, the European Central Bank (ECB) and the International Monetary Fund (IMF). After five years of recession in Greece, the current economic crisis has influenced every aspect of the public and private life, leading to a decrease in the living standards of most citizens and to new consumer patterns, reinforcing feelings of uncertainty, and most significantly creating a different social and cultural framework [3].

It must, though, be pointed out that it is not possible to fully evaluate the impact and the extent of this economic crisis since the recession phenomenon is still ongoing and its consequences in many sectors are uncontrollable [4].As data collection remains an important challenge, it is widely acknowledged that the recession has already influenced, and will further

\footnotetext{
${ }^{\mathrm{a}}$ Corresponding author: pkostagiolas@ionio.gr
} 
influence the operation and services of Academic Libraries leading to re-evaluation of their strategies and re-construction of their policies [5].Taking into consideration the continuous emergence of new information and communication technologies, the longawaited recovery may come in a time when libraries will be probably different to what they were before 2008 [6]; this is not surprising and in hardly constitutes a unique occurrence. This paper initially provides an overview of the economic crisis impact on academic libraries and finally proceeds by presenting the results of an empirical survey. This survey is based on a similar research conducted by University College of London (UCL) and attempting to include all academic libraries in Greece. The survey is conducted through semi-structured interviews in a sample of Academic Libraries' directors that finally participated. The aim of this research is to record the perceptions on the top library management executives in light of the economic crisis presenting their efforts to advance innovation, implement alternative leadership practices within the present financial and social vortex by relying on their creativity and viable cooperation schemes.

\section{Libraries as treasuries of knowledge in a globalised environment}

Academic libraries over their long history played a dynamic role by serving the research and educational needs of the academic community being simultaneously at the peak of innovation and by exploring new technologies and opportunities.For a better understanding of their leading role, we must bear in mind that their policies and profile, being often relatively exempt from political or economic restrictions, led to the production of innovative, even revolutionary ideas and methods [7]. In Renaissance North Italy, for example, academic libraries, apart from being enriched with printed copies of the current the scientific output, evolved due to complex scientific and social reasons so as to better serve the scientist's needs. During the 19th century in Great Britain among the members of the famous Bibliographical Society were librarians that, apart from their knowledge and experience, offered a systemized approach to book and library studies playing thus a dynamic role in the study of the book and the function of libraries. "Free to all, open to all" libraries have been a common value of the Western World concerning libraries and a privilege gained for all people from the Enlightenment and the Industrial Revolution till now. It is noteworthy that libraries existed and exist in the centre the cities, library buildings being among of the most recognizable urban structures declaring in this way the strength of knowledge and the value of information [8].

The mission and values of academic libraries are certainly interrelated with the role of universities and more specifically, apart from the research and the teaching, with their policies that have in turn economic and social impact. The so-called decline nowadays of humanistic sciences may be one of the faces of Janus, while some point out the significance of what on first glance appears not to be useful or practical or financially valuable. Moreover, libraries ought to utilize other types of intangible resources for innovation and development. In a world in which the information is the main product and access to information is of significant value, new information technologies and services offer innovative opportunities for value creation [9]. Nowadays, above and beyond the economic crisis, the ever-changing information environment creates probably the most important challenge for libraries. Digitization may be one of them [10]; additionally, the social media that build communities of readers create a new framework for the libraries which in their turn have to exploit the opportunity for attracting library users and empower their presence in the local community. Recession actually forces people to visit "free to all, open to all" libraries. Furthermore, the knowledge economy may indeed increase the social value of information institutions providing opportunities for growth [11].Problems and challenges seem though to go hand in hand; it must also be clarified that highlighting the opportunities related to the recession does not mean rejecting its inevitable negative effects to information institutions [12].

Libraries have always been treasuries of knowledge and librarians and information scientists have been considered gatekeepers to the treasures of knowledge, of information presented mainly in the traditional form of the printed word. Thus, libraries are dynamic institutions of memory that strive to provide access to information and knowledge to all that care to use their resources. As libraries are still treasuries of the memory of the community and of knowledge, being historically at the centre of the cities, towns and universities, they hold another important role: that of exhibiting and making use of the tradition and history of the local community [13]. This provides an opportunity to the library to explore alternative funding strategies. Indeed, active participation of the library in the educational and research university processes may go hand in hand with the development of reading policies especially in times when the demand of library services is increasing. Apart from these ways of reaching the reading audience, creating readers and then allowing them to develop, social media nowadays offer the opportunity of building communities of readers who take an active dynamic role by expressing their attitudes and exchanging opinions. Libraries have always been striving for a more active participation of readers; nowadays engagement of the reader is further encouraged by information technologies, multimedia, augmented multimedia and social media. Library services have to be constantly updated, collections ought to be developed and technologies to be implemented as soon as they are made available.

Libraries through the centuries have developed collaborations and co-operations so as to share, exchange, solve, develop and re-develop policies, discuss, plan and act. They are sharing tangible and intangible resources and develop economies of scale and scope. For example, library alliances negotiate better with publishers and other stakeholders so as to get more favorable agreements [14]; moreover, they can commonly use information resources and infrastructure [15] and develop innovative 
services [16]; cataloguing and documentation are shared for decades. Actually, among the advantages that alliances have for Academic Libraries we may recognize the following [17]: sharing information and other resources, companionship programs promoting teamwork within the library, associations with other libraries whether of the same kind and interest or/and located in the same area, collaboration programs based on relations that the library establishes with other units and staff members within the university, links with libraries and organizations of the same type and nature in other countries. More specifically, library consortiums may take different forms and have different dynamics [17]: they may be internal, among staff members, between the library and other libraries [18] [19] [20] between the library and other units or departments of the academic institution [21], between the users and the library [15] and finally between the library and the wider community [17]. Developing viable cooperative operational models and reinforcing already existing ones may prove to be profitable during the recession through the creation of economies of scale [22].

\section{A brief overview of the economic crisis impact on Academic Libraries}

The economic crisis has not affected only the Academic libraries in Greece, but has impacted the libraries all over the world and certainly in Europe [23] [24] [25]. The most profound impact is related to budget reductions and results from the corresponding fiscal crisis. Just to mention only a few, academic libraries with budget reductions include the academic Library of East Tennessee [26] as well as the reductions in the academic libraries of Emory University and the University of Washington [27]. Moreover, it is generally accepted that the number of staff allocated in the academic libraries will never be the same again [28]. In Great Brittan the library services have been affected by the economic crisis [29]. In Ireland, after a period of prosperity, the academic libraries have also been hit by the economic crisis [24].

The reduction in research funding, as well as, in higher education institutional budgets increases the competition for the allocation of funding within the institutions. In most cases, the aforementioned background of competition reinforces budget reductions in academic libraries [30]. However, the true extend of the economic crisis impact is difficult to estimate [5].

On the other hand the economic crisis may also be seen as an opportunity for innovation and adjustments based on the new information technologies such as digitization [10]. The sustainability of an Academic Library may also depend on its ability to develop cooperation's and alliances with other institutions and organizations [17]. The academic libraries need synergies of many types in order to "communicate" and prove their value in the wider socioeconomic environment. According to Nicholas et al. [31] during the economic crisis, academic libraries should share openly ideas and experiences and promote cooperations [20] [18] [19] [27]. These can be among the academic library and other university units [21] [32]; among the academic library and other private or public organizations [17]; and also among the library and its' users [15]. The economic crisis can further urge innovation capabilities and promote an outreach culture for library management [34]. The professional communities need to advocate the role of academic libraries in promoting teaching and research; while the central role of the library in any university should be made clear [33]. On the other hand, the more the economic crisis deepens the demand for the services provided by the academic libraries increases due to the reduced income of the individuals, e.g. students of all levels etc. [2]. This phenomenon of increased demand in library services can actually provide an excellent argument for the important socioeconomic role of the libraries in periods of economic recession [12] [35] [36]. Therefore, the basic goals of the academic libraries still include the management of scholarly information and communication, the improvement of research and educational tools as well as the development of new ones.

\section{The impact of the economic crisis on academic libraries in Greece: Empirical evidence}

The largest part of Academic Library financing in Greece comes from the budget of higher and technical education institutions and thus they are fully dependent upon state funding. Budget cutbacks are the most obvious consequence of reducing state expenses. In Greece, higher education budgets receive further cuts every year of the recession. Additionally, European Development programs which significantly helped Academic Libraries have concluded by May 2009. According to the available information, in the year 2010 there was an overall total reduction of $31.3 \%$ in state funding, as compared to 2006 . A comparative analysis of total annual expenses demonstrates the existence of an upward trend for University Libraries until 2009; however, this trend was suddenly discontinued in the following years (2010-2012) marking a sharp fall of around $50 \%$. For academic libraries in Technical Education Institutes this unfavorable situation had started one year before, in 2008 , with a significant drop which reached about $50 \%$ in the year 2009 and remained at the same levels afterwards. In the past two years, operational expenses were also significantly reduced around $50.0 \%$; while staff members dropped of around $20 \%$ in 2010 , mainly due to the dismissal of many contract agents employed through European Programs, which closed approximately in May 2009.

\subsection{Profile and methodology}

In Greece there are Academic Libraries in 22 Higher Education Institutions and 15 higher Technical Education Institutes. The survey was conducted during the summer of 2013, more specifically from the middle of July till the end of August and was partly based on a similar research conducted by University College London [23]. The aim of the research was to record and study the opinions and 
experience of directors of academic libraries in Greece in a moment when the economic crisis was more than ever present, influencing deeply library services. The research was conducted through interviews with the directors either through the telephone or, if requested by the directors, via email. More specifically, twenty directors participated and answered to the following seven questions:

I. Which are your estimations for the growth/evolution of the Greek economy in the next couple of years?

II. Which influences do you consider more significant and unfavourable / negative on the operation of the academic libraries?

III. According to your estimations, will more cutbacks at the academic libraries take place?

IV. According to your estimations, is it possible mergers or even shutdown of academic libraries to take place?

V. Do you consider the economic crisis as a challenge too for (the) academic libraries?

VI. Do you base your decisions primarily on economic criteria or according to other factors?

VII. Do you believe that collaborations between (the) academic and / or another kind of libraries could encourage the development of libraries during the economic crisis?

\subsection{Results}

Results are representative of the present situation experienced by Greek academic libraries. In that framework of the economic recession and its influence on the management of these libraries through mergers and cutbacks, directors were called to express their opinions and estimations. Actually, the reality for all libraries, including the academic ones, is budget cutbacks that have inevitably influenced the policy and the strategies of libraries. From this point on, there are various representative examples.

Regarding the first question, the perspective of the growth of the Greek economy in the next couple of years responses were characterized as negative or in the context of the cutbacks that are planned from the Government giving sometimes an optimistic point of view because of the stability at the existing levels of development.

Regarding the influence that the economic crisis had on the operation of academic libraries, answers given were focused on the cutbacks of budget but also on the reduction of personnel/staff. This is, however, not only a feature in Greece. According to statistical data provided by LAMPOST [37] and published by the Loughborough University, at the beginning of the crisis in the United Kingdom there was a reduction of employees amounting to $2.6 \%$ in 2009 and $1.8 \%$ for information scientists. In Ireland, a decade of Academic Library progress was followed by the crisis [24] and libraries were obliged to cut back their staff by $9 \%$ by the end of 2011 , as compared to the number of their staff members in 2008.In Greece, the reduction of staff is in cases dramatic due to the fact that significant part of the personnel had not a permanent position at the libraries. Furthermore, cutbacks in the acquisitions either of printed or of electronic material are changing the function and the operation of libraries; in economically hard times libraries are supposed to widen their audience by encouraging new readers to join as members; but if the libraries cannot satisfy their needs and meet their expectations, then part of the challenge is lost.

In that framework, library directors have identified among the problems difficulties in the creation of academic repositories. Moreover, many of them have expressed the fear that the conditions will get worst and cutbacks will continue reducing the active participation of academic libraries in the educational and research process in universities. Regarding the possibility of mergers and close-ups of libraries, the majority of the directors participating in the survey estimate they will take place in the near future. Mergers were also considered in the possibility of larger institutional mergers.

It is noteworthy that the economic crisis was perceived as a challenge for libraries too, giving thus another point of view. More specifically, it was identified that the crisis forces people and institutions to be more competitive and creative, to demonstrate the value of libraries and to imagine operating in a more rational manner having developed strategies and implemented internal restructuring. Furthermore, the knowledge economy may indeed increase the social value of information institutions providing opportunities for growth [11]. From this point of view, collaborations and synergies between academic libraries or between academic and other types of libraries could be positive as vehicles of development in hard economic times. Successfully utilizing the opportunities presented by technology, institutions values and their intellectual capital could lead to collaborations that could benefit all stakeholders. For example, the HEAL-Link federation is the largest academic library consortium in Greece and is constituted from the total sum of 37 Academic Institutions (22 Universities and 15 Technological Institutions), 14 Research Institutions, the Academy of Athens, the National Library of Greece, the Hellenic Parliament Library, the Pedagogical Institute, the National Agricultural Research Foundation, and the University of Cyprus. Another example is the Hellenic Economic Library Network H.E.LI.N. The mission of the Network is to promote cooperation among the member libraries, with the consent and support of their respective administrations, in order to exchange services and resources related to their collections and various sources of economic content. The ultimate goal of the member libraries is to provide higher quality and more effective services to their user communities.

\subsection{Discussion}

The majority of the directors estimate that in ensuing years the problems will increase, mainly due to expected budget cutbacks. Among the difficulties they stress recognize is staff reduction, cutbacks in acquisitions, and 
problems in the function of libraries; mergers are also mentioned as a negative perspective. On the other hand, the crisis creates challenges; among these are the augmented needs and expectations of readers who turn to libraries. The demand for library services is really increasing but at the same time opening hours are in many cases reduced due to the reduction of staff, while cutbacks in acquisition policies practically mean that the library cannot always satisfy the needs of the readers. Meanwhile virtual and on site visits per person increase; that is the challenge for libraries which in their turn have to continue, empower and enrich their role as treasuries of knowledge. New information and communication technologies undeniably help them while collaborations and synergies form part of the challenges.

Undoubtedly, the economic crisis has influenced the daily operation of libraries, bringing about several changes, for example, in acquisitions, open hours, staff etc. What the crisis could not change is the role of libraries which is further empowered creating thus a historical continuity between the "open to all, free to all" libraries of the Enlightenment - Industrial Revolution and the Digital Revolution of our era. Furthermore, reading policy should be high in the priorities of the management of libraries giving emphasis not always in attracting and nurturing new readers, which is the first step, but also encouraging reader development. In that framework, new information technologies, especially social media, may help towards this aim by building communities of readers. Libraries already use them for strengthening the relationship between them and their users, for example via book blogs and book clubs. What we may ask our selves is whether the crisis is only economic and not as well a crisis of values. In this framework, what does the library mean and what is the distance between info-poor and info-rich? As in the publishing industry, problems that seem to be new are rather old, options that seem to be innovative are already used for centuries; in this context, old strategies are rediscovered in a time when digital libraries, thus services without physical appearance, seem to take a leading role. On the other hand, the library as a meeting place, as a place of various activities, in the centre of tows/cities, as a symbol not only of knowledge but mainly of the "free to all, open to all" access to information services continues to have a strong impact.

\section{Conclusions}

Economic perspectives need to be combined with the needs, priorities and values of library users. In this framework, in periods of recession and crisis, promoting the value of libraries and non-profit organizations seems to be of high importance [38]. At the same time, and most distressingly, libraries run the risk of failing to meet users' expectations being thus marginalized within their community if they do not manage to take advantage of the challenges and satisfy the readers' needs. Successful application of new information technologies and social media, creativity, synergies, collaborations are among the challenges. Undeniably, the non-profit character of academic libraries makes them part of an operational model that utilizes public funding so as to serve the University to which they belong [13]. Taking always into consideration the different traditions, policies and approaches of each institution, academic libraries in Greece ought to have a common policy regarding important issues in the heart of which there is the need for demonstrating library value. The creation of novel highly valued services can be based on the intellectual capital of the library [39] also highlights the need of library management to focus on human capital in times of crisis. Furthermore, active participation of the academic libraries in the educational and research university processes will promote achievements in research and further encourage cooperation with other institutional units [9]. Due to the recession, some of the main goals of academic libraries, such as providing access to high quality academic information, developing research tools, providing educational infrastructures, may be served and supplemented in alternative ways, through cooperation.

\section{References}

1. W. Grant, G. Wilson, The global financial crisis: The Rhetoric of reform and regulation. Oxford University Press. (2012)

2. P. Kostagiolas., E. Papadaki, G. Kanlis, S. Papavlasopoulos, Advances in Librarianship, Responding to Crises with Alliances: Evidence from an Academic Library Survey in Greece., 36, pp. $247-$ 279 (2012)

3. M.G Arghyrou, J.D. Tsoukalas, CESifo Working Papers, The Greek debt crisis: Likely causes, mechanics and outcomes, 3266 (2010)

4. R, Harper, S. Corrall, New Review of Academic Librarianship, Effects of the economic downturn on academic libraries in the UK: Positions and projections in mid-2009. 17, 1, pp. 96-128 (2011)

5. D.M. Davis, Chicago, IL: American Library Association, The condition of U.S. libraries: Academic library trends, 1999-2009. (2009). http://www.ala.org/ala/research/librarystats/academic Condition of Libraries 1999.20.pdf

6. J. J. Regazzi, The Journal of Academic Librarianship U.S. Academic Library Spending, Staffing and Utilization during the Great Recession 2008-2010, 39, pp. 217-222. (2013)

7. M Kumaran. Chandos Publishing, Oxford, Information Professional Series, Leadership in Libraries. (2012)

8. J. R. Matthews portal: Libraries and the Academy, Valuing information, information services, and the Library: Possibilities and realities, 13, 1, pp. 91112. (2013)

9. Y. Noh Aslib Proceedings, The impact of university library resources on university research achievement outputs. 64, 2, pp. 109 - 133 (2012)

10. A. Powell, Journal of Library Administration Times of crisis accelerate inevitable change. 51, 1, pp. 105129 (2011) 
11. P.A. Kostagiolas, Oxford, UK: Chandos Managing intellectual capital in libraries: Beyond the balance sheet. (2012)

12. Goulding, Journal of Librarianship and Information Science, Credit crunch: The impact on A libraries, 41, 3, pp. 3-6. (2009)

13. Arts Council England Evidence review of the economic contribution of libraries. (2014)

14. C. Banou, P. Kostagiolas, Proceedings ELPUB2007 Conference on Electronic Publishing, Managing Expectations for Open Access in Greece: Perceptions from the Publishers and Academic Libraries, (2007)

15. N.J Meyer, I.R. Miller, College \& Undergraduate Libraries The Library as service learning partner: $A$ win-win collaboration with students and faculty, 15, 4, pp. 399-413 (2008)

16. J. W. Marcum, The Bottom Line: Managing Library Finances, Partnering for innovation and sustainability, 21, 3, pp.82-84. (2008)

17. , L.M. Anglada Library Management, Collaborations and alliances: Social intelligence applied to academic libraries, 28, pp. 406-415. (2007)

18. R.M. Dougherty, American Libraries, Prescription of financial recovery: The current economic crisis holds opportunities. 40, 6, pp. 50-53. (2009)

19. T. Kidd, The Serials Librarian, The view from the UK: The economic crisis and serials acquisitions on an offshore island, 59, 3/4, pp. 384-393. (2010)

20. E. Cryer, K.S. Grigg, Journal of Electronic Resources in Medical Libraries Consortia and journal package renewal: Evolving trends in the “big package deal?”. 8, 1, pp. 22-34. (2011)

21. S.E. Montgomery, J. Miller, College \& Undergraduate Libraries, The third place: The library as a collaborative and community space in a time of fiscal restraint, 18, 2/3, pp. 228-238. (2011)

22. W. Günter, R. Erway Museum Management and Curatorship, Think Global, Act Local-Library, Archive and Museum Collaboration. 24,4. (2009)

23. Charleston Observatory The economic downturn and Libraries: Survey findings. University College London. (2009). http://dx.doi.org/10.1108/PMM-052015-0016

24. J. Cox, An Leabharlann, The Irish Library Academic libraries in challenging times. 19, 2, pp. 7-13. (2010)

25. American Library Association. Academic libraries in the United States: Statistical trends. Chicago, IL(2011).

http://www.ala.org/ala/research/librarystats/academic /academiclibraries.cfm

26. L. Adebonojo, M. Ellis, K. Campbell, M. Hawkins, Reference Services Review, Redirecting library instruction based on socioeconomic data. 38, 3, pp. 398 416. (2010)

27. M. K Throumoulos, The Bottom Line: Managing Library Finances, Exceptional service during and after deep serial cuts, 23, 1, pp. 24-28. (2010)

28. Medeiros, N., OCLC Systems and Services: International digital library perspectives Transformation: Next generation technical services at the University of California Libraries., 27, 1, pp. 6-9 (2011)

29. I. Mori, The impact of the economic recession on university library and IT services: Final report for JISC, SCONUL and UCISA. (2009). http://www.jisc.ac.uk/media/documents/publications/ libsitimpacts.pdf

30. M. Reid, The Bottom Line: Managing Library Finances Building an academic library fundraising program 'from scratch", 23, 2, pp. 53-56 (2010)

31. D. Nicholas, I. Rowlands, M. Jubb, H. R. Jamali, The Journal of Academic Librarianship, The impact of the economic downturn on libraries: with special reference to university libraries, 36, 5, pp. 376-382 (2010)

32. S.M. Pritchard, Library and the Academy Crises and opportunities, 9, 4, pp. 437-440 (2009)

33. R. Volentine, C. Tenopir, Aslib Proceedings, Value of academic reading and value of the library in academics' own words, 65, 4, pp. 425-440(2013)

34. P.A. Kostagiolas, A. Margiola, A. Avramidou, Library Review, A library management response model against the economic crisis: The case of public libraries in Greece, 60 6, pp. 486-500(2011)

35. C. Rooney-Browne, Library Review, Rising to the challenge: A look at the role of public libraries in times of recession, 58, 5, pp. 341-352 (2009).

36. P. Kostagiolas, Library Management, Managing knowledge capital in public libraries for a knowledge-driven socioeconomic environment, 34 8/9, pp. 677-689(2013)

37. LAMPOST (2012), Loughborough University, Libraries, Archives, Museums and Publishing Online Statistics Tables, http://www.lboro.ac.uk/microsites/infosci/lisu/lampo st10/exp10.html

38. P. Calvert, A. Goulding, Performance Measurement and Metrics, Narratives and stories that capture the library's worth, 16, 3, pp. 276-288 (2015)

39. P.A. Kostagiolas, S. Asonitis, A. Woodsworth, Advances in Librarianship Managing intellectual capital in libraries and information services, 33, vol. 31-50 (2011) 